\title{
THE IMPACT OF CONTROL PROCESSES ON MANAGERIAL DECISION MAKING
}

\author{
Jan Kráčmar, Miroslav Uhliar \\ University of Economics in Bratislava, Slovakia \\ E-mail: jan.kracmar@euba.sk, miro.uhliar@gmail.com
}

\begin{abstract}
Control and managerial decision function activities have an important share in the managerial work. The paper The Impact of Control Processes on Managerial Decision Making describes the share of managerial control and decision function on the total managerial work. It also evaluates the influence of control activities on the decision making functions of different-level managers in questioned companies doing business in Slovak Republic. The results were obtained thanks to the surveying method. 392 participants took part in the research, which was made in two phases (in 2008 and 2010). The findings show the importance of managerial functions of control and decision making. They identify over 21\% of control function- and almost $30 \%$ of decision making function share on total managerial work. There were discovered, many positive effects of control function on managerial decision making, while only few and insignificant negatives were identified.
\end{abstract}

Key words: manager, control function, managerial decision making, evaluation, manager job content.

\section{Introduction}

The theory of management has known the matter of different managerial functions since the era of Henry Fayol. (Majtán, 2009, p. 20) These managerial functions are a subject of a wide range of literature, being characterized from both the sequential and parallel point of view (Szabo, 2010, p. 9). Less attention, however, has been paid to the different relationships between the elements of the managerial functions system and their mutual influence. Especially the area of the managerial control function, with its connection to the managerial decision making, has not been explored adequately. For this reason the research was aimed at control and managerial decision making, while the article only contains parts which are connected to the process of identifying the share of the mentioned functions on the total manager's work and the influence of the control on the decision making process as well.

Directive activity, by other words management, can be characterized as derived dispositive production factor, which is represented by managers (Majtán, 2009, p. 113). Generally the managers are expected to get information from the company and its surroundings necessary for their decision making (Porvaznik, 2011, p. 141). It is the control itself, as a set of mechanisms, systems, procedures and rules, which creates suitable conditions for good-quality and effective management of the company (Synek, 2011, p. 424).

The importance and recency of the relationship between control and decision-making increase especially due to crisis phenomena. Timely identification of arising crisis is mostly important for the company (Zuzák, 2009, p. 78) in order to quickly decide about implementing necessary actions. Unless the rising problem is early identified and dealt with, it can transform into a real threat (Veber, 2009, p. 98). Almost every company develops its own internal control system, which can be used and incorporated into the system of early warning, too (Zuzák, 2009, p. 156). 
Sometimes it is forgotten that the control function is an inseparable part of planning, organizing and decision making (Majtán, 2009, p. 233). Whereas even control as a managerial function plays an important and irreplaceable role in a manager's daily work. It cannot be omitted at the beginning of every task that means in the phase of planning. It is crucial in the implementation phase and it is essential within the final evaluation of achieved results, which on the other hand contribute to the process of planning of the next task.

Basically managers are not aware, of the appropriate proportion of the control processes they should include in the everyday practice. They have a vague idea of how much time they should dedicate to decision making. Plenty of managers do not realize the importance of control and its outcomes in the managerial decision making. It is necessary to make a research to document these facts.

\section{Research Focus}

The research was targeted on different-level managers who were also working in distinct functional areas within the companies doing business in Slovak economy. The main objective of the research was to identify the share of managerial functions, mainly control and decision making, in the managers' work. At the same time the research was focused on identifying the influence of control on the managerial decision making. Considering the extent, this was a unique research carried out in Slovak economy but only several questions from the original survey were chosen from for this article.

\section{Methodology of Research}

\section{General Background of the Research}

The survey research was made in two phases, the first in 2008 and the second in 2010. The reason was to eliminate the impact of negative economic situation around the world and in the analyzed environment. Electronic and personal forms of data collection were used in the research. The mentioned survey had been tested by an expert. It contained different types of questions. There were open, semi-open, closed and scalable questions based on Likert scales. All these enabled the respondents fully present their opinions and observations from their managerial experience.

The first part of the survey contained questions destined to characterize the company and the manager according to certain attributes, such as number of employees, size of the company, form of the ownership, business area, establishment era, number of managerial levels and functional and organizational level of the managers themselves.

The second part contained inquiries focused on the connection between the control function and decision-making of the managers. It contained many different types of questions and gave participants a possibility to fully express their opinions and remarks.

\section{Sample of Research}

The sample size was 392 managers. The $95 \%$ confidence interval was used to identify the survey sample. The population was identified according to the research of the Saratoga Institute, which defined the manager scope at 8.3 employees to one manager in Slovak economy (Hunčík, 2006, p. 4). The population of 279217 managers was set up from the total number of working force which was 2317500 people in 2010. The size of statistic relevant sample (384 
managers) was even exceeded by the reached sample of 392 managers. If we considered the Volume 3, 2012

conditions from 2008, the needed sample of managers would be of the same size.

\section{Instrument and Procedures}

The research was supported by the University of Economics in Bratislava. The data were collected through the method of surveying. The received data were analysed by using the statistical software SPSS for Windows and the MS Excel 2007 with data analyses add-on as well.

\section{Data Analysis}

The methods of descriptive statistics, e. g. frequency, pivot and descriptive tables, pie and bar charts, were used during the data analysis. Beside this Cramer V coefficient, Eta coefficient, $\mathrm{P}$ values, binomial test, standard deviation and others were applied, too.

\section{Results of Research}

Examination of the control functions share on total managerial work

The control function share was determined according to the evaluation of the survey question: "Describe the share [in \%] of the control functions on your total work."

A) Construction and the objective of the question

The question was made as open, so that the participants had the possibility to write an exact percentage of the control functions share on their managerial work. The objective was to identify the share of the control functions on the total managerial work.

B) Result

Table 1. Percentage intervals of the managers' answers to the question of the control functions share on the total work.

\begin{tabular}{|c|c|c|c|}
\hline Interval [\%] & $\mathbf{N}$ & Share [\%] & Cumulative N [\%] \\
\hline$<=10$ & 148 & 37.76 & 37.76 \\
\hline$>10-20$ & 100 & 25.51 & 63.27 \\
\hline$>20-30$ & 76 & 19.39 & 82.65 \\
\hline$>30-40$ & 48 & 12.24 & 94.90 \\
\hline$>40$ & 20 & 5.10 & 100.00 \\
\hline Total & 392 & 100.00 & $x$ \\
\hline
\end{tabular}


PROBLEMS

OF MANAGEMENT IN THE $21^{\text {st }}$ CENTURY Volume 3, 2012
46

Share $[\%] \quad-\square-$ Cumulative $\mathrm{N}[\%]$

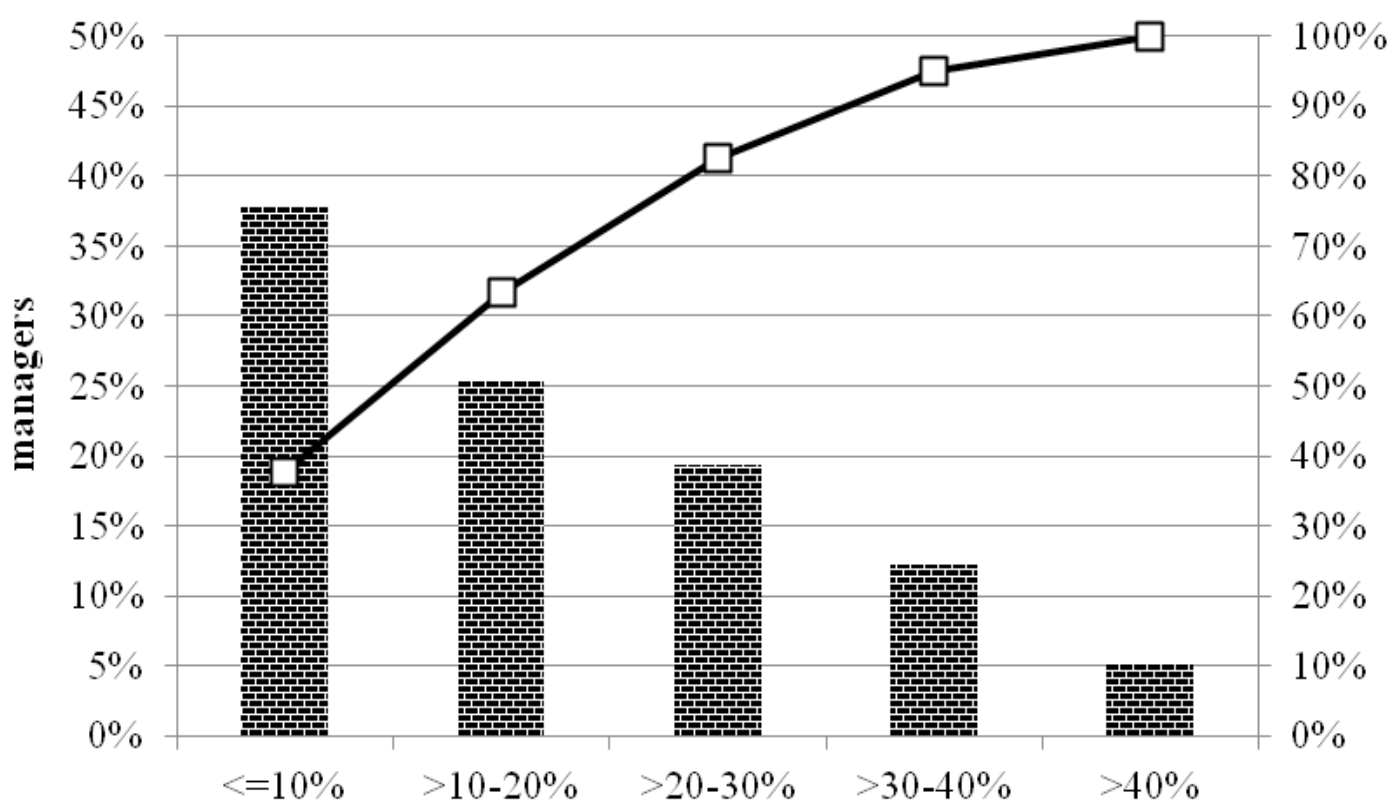

share of control functions - intervals [\%]

Figure 1: Percentage intervals of the answers to the question of the control functions share on the total work.

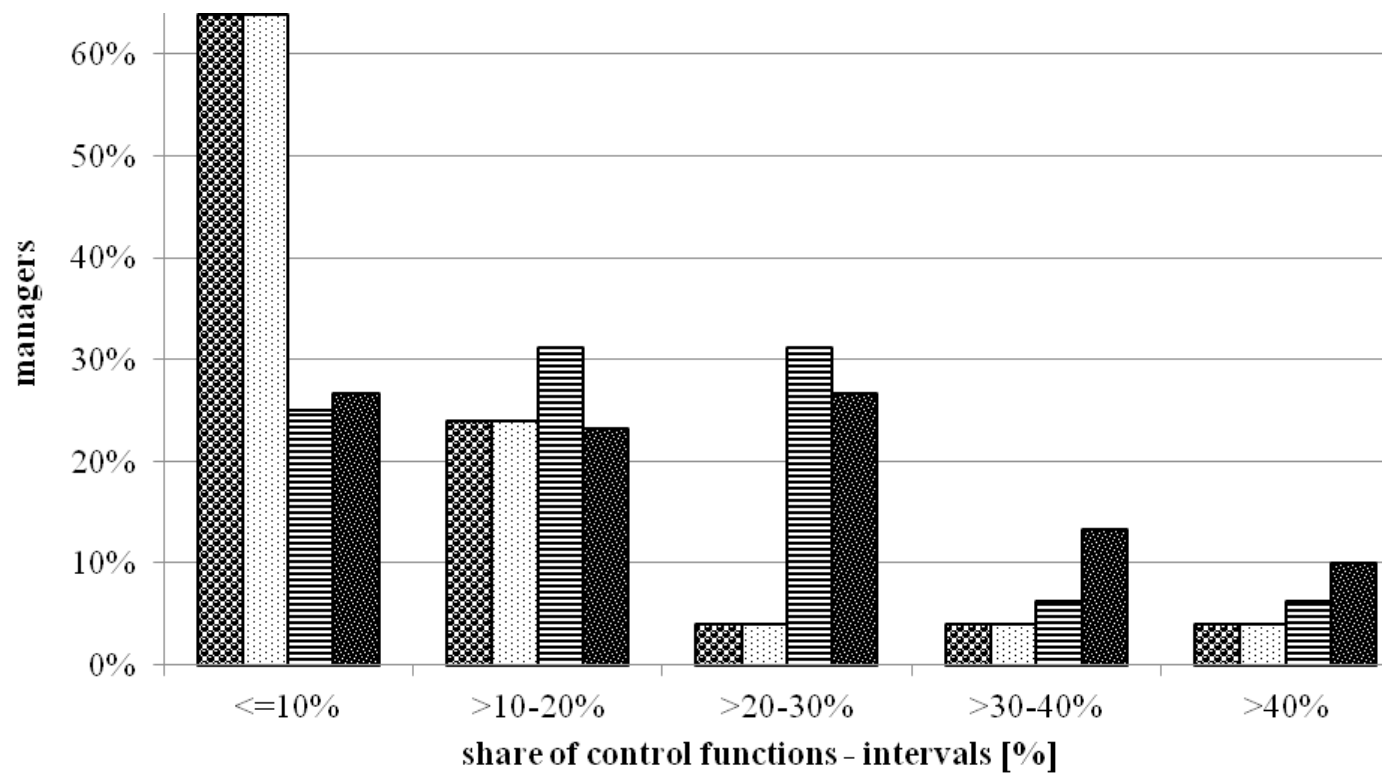

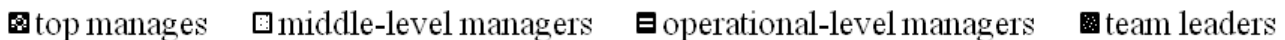

Figure 2: Percentage share of the different-level managers' control functions on their total work. 
A decisive part of managers (38\%) stated that the control functions make up to $10 \%$ of their total work. The second biggest group, nearly $26 \%$, said that the control functions form a 10 $-20 \%$ share on the total managerial work. Next interval of managerial work share of $20-30 \%$ was stated by more than $19 \%$ of managers. The interval of $30-40 \%$ was reflected by $12 \%$ of managers. On the other hand only $5 \%$ of managers admitted a share of more than $40 \%$.

Considering the cumulative sum of the answers we can reckon that the interval of less than $20 \%$ share refers to approximately $63 \%$ of the participants.

During further examination of the control function according to different organizational levels of the managers it was confirmed that the top managers dedicate only a small part of their work to control activities. We discovered that more than $60 \%$ of the top and middle-level managers spend less than $10 \%$ of their work on control activities. On the other hand, managers of lower levels use the control functions in much wider range. The interval of $20-30 \%$ was mostly defined by operational managers and team leaders.

The next tab shows the average rate of control activities on the total managerial work.

\section{Table 2. Average share value of control functions on the total managerial work.}

\begin{tabular}{|l|c|c|c|}
\hline & N & Average [\%] & St. deviation [\%] \\
\hline The share of control functions on the total managerial work & 392 & 21.12 & 14.49 \\
\hline
\end{tabular}

\section{Examination of the decision-making functions share on total managerial work}

The decision-making share was determined according to the evaluation of the survey question: "Describe the share [in \%] of the decision functions on your total work."

A) Construction and the objective of the question

The question was made as open, so that the participants had the possibility to write an exact percentage of the decision functions share on their managerial work. The objective was to identify the share of the decision functions on the total managerial work.

B) Result

\section{Table 3. Percentage intervals of the answers to the question of the decision functions share on the total work.}

\begin{tabular}{|c|c|c|c|}
\hline Interval [\%] & $\mathbf{N}$ & Share [\%] & Cumulative N [\%] \\
\hline$<=10$ & 64 & 16.33 & 16.33 \\
\hline$>10-20$ & 116 & 29.59 & 45.92 \\
\hline$>20-30$ & 80 & 20.41 & 66.33 \\
\hline$>30-40$ & 32 & 8.16 & 74.49 \\
\hline$>40$ & 100 & 25.51 & 100.00 \\
\hline Total & 392 & 100.00 & $x$ \\
\hline
\end{tabular}


PROBLEMS

OF MANAGEMENT IN THE $21^{\text {st }}$ CENTURY $\begin{array}{r}\text { Volume 3, } 2012 \\ \hline 48\end{array}$

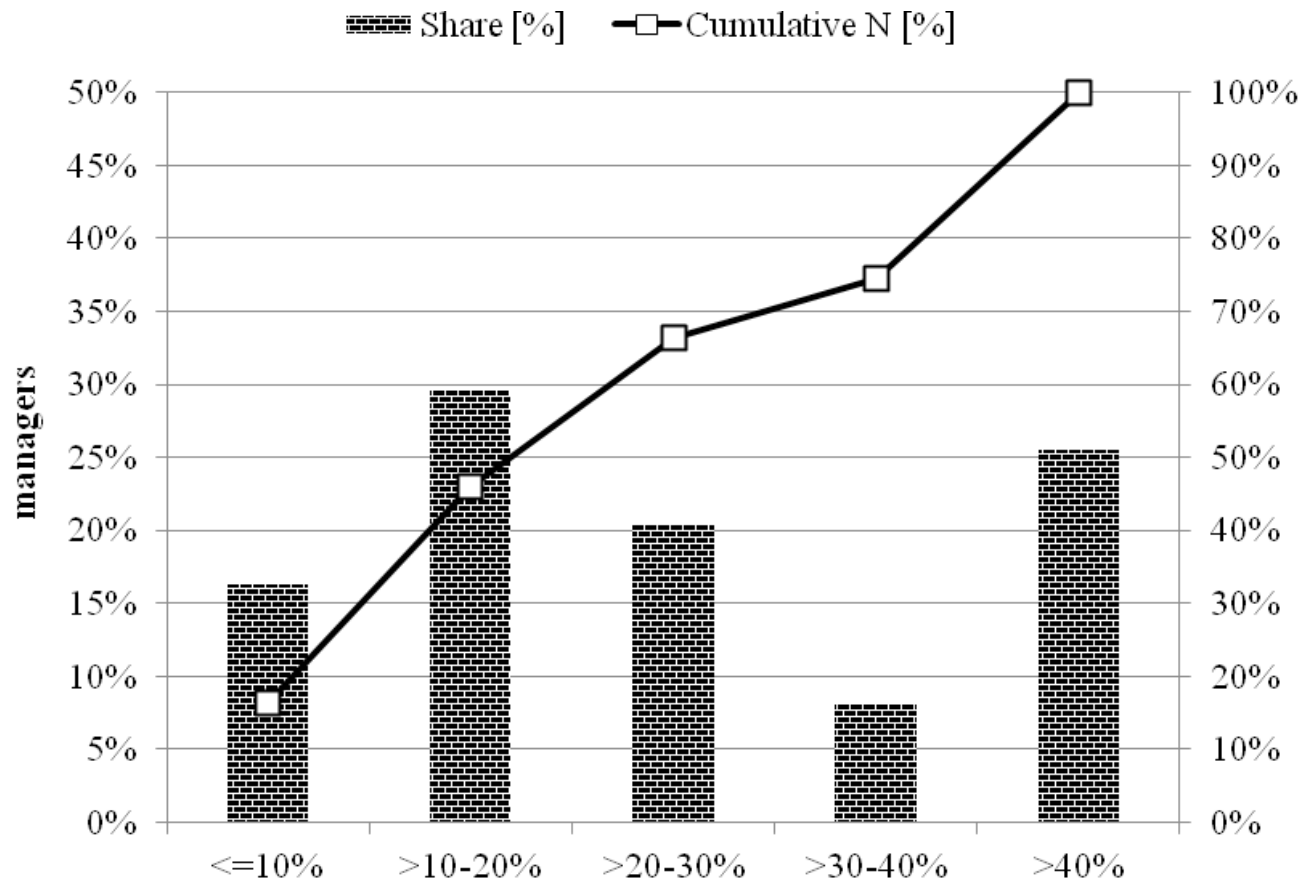

share of manager's decission functions - intervals [\%]

Figure 3: Percentage share of managers' decision functions on their total work.

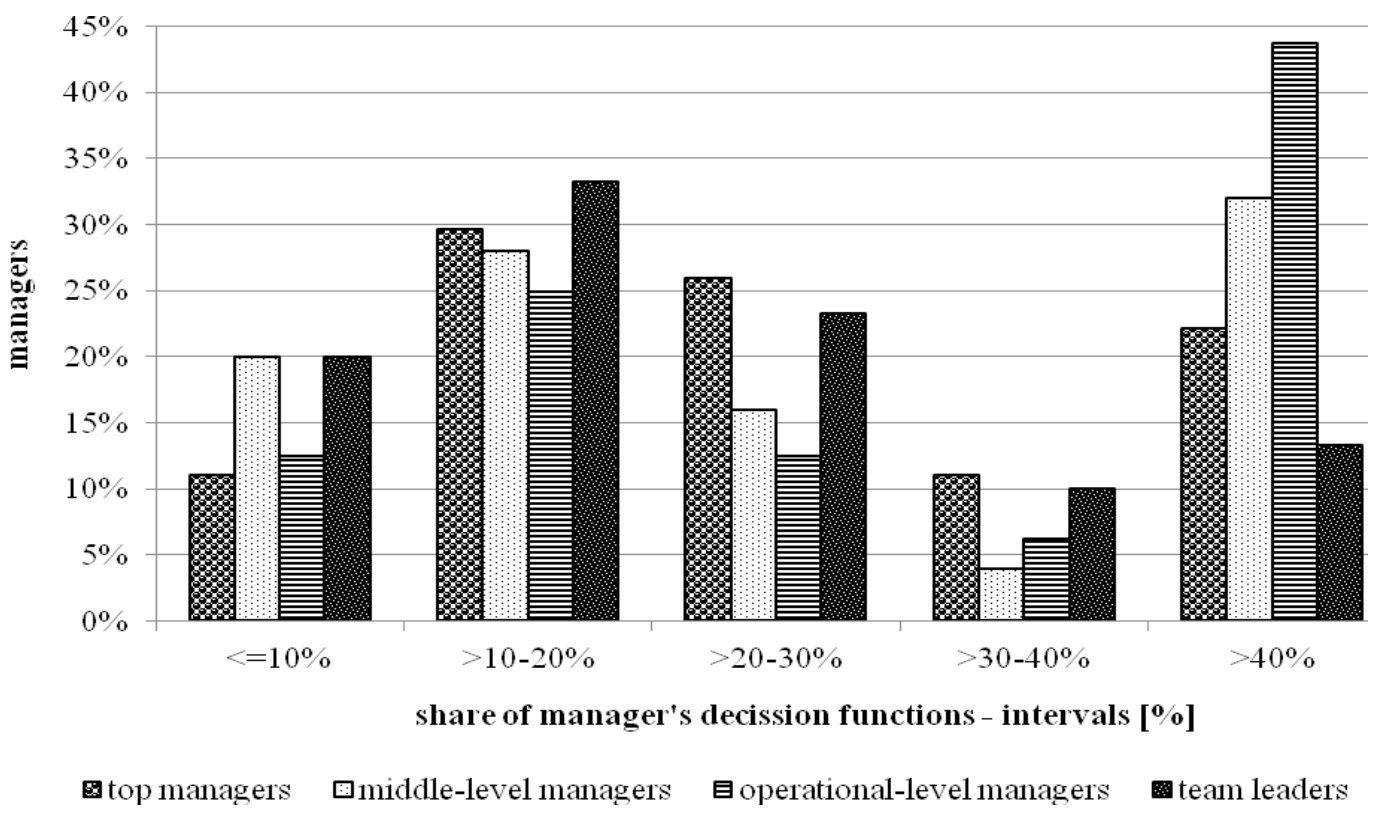

Figure 4: Percentage share of the different-level managers' decision functions on their total work.

The most frequent answer, stated by nearly $30 \%$ of participants, was that the total share of the managerial decision function on the total work was from 10 to $20 \%$. On the other hand, 
the least number of participants, approximately $8 \%$, defined the decision making functions in Volume 3, 2012

the interval of 30 to $40 \%$ on their total work.

Considering the cumulative sum of the answers we can reckon that the interval of less than $30 \%$ share included approximately $66 \%$ of the participants.

Further examination of the decision-making function according to different organizational levels of the managers brings us interesting remarks. Almost 30\% of the respondents from the top management level marked the interval of $10-20 \%$. More than $20 \%$ of the top managers chose the interval of over $40 \%$. Nearly $45 \%$ of the operational managers dedicates over $40 \%$ of their time to the decision-making functions.

The next tab shows the average rate of decision-making activities on the total managerial work.

Table 4. Average share value of decision functions on the total managerial work.

\begin{tabular}{|l|c|c|c|}
\hline & N & Average [\%] & St. deviation [\%] \\
\hline The share of decision functions on the total managerial work & 392 & 29.69 & 16.89 \\
\hline
\end{tabular}

Examination of how the control system affects manager's decision making

The influence of the control system on manager's decision making was determined according to the evaluation of the survey question: "Please indicate if and to what extent do the existence, activity and outcomes of the control functions resp. control system affect your decision making."

A) Construction and the objective of the question

The question was a closed one. The objective was to identify the effect of control activities and control system outcomes on the managerial decision making.

B) Result

Table 5. Statements on the effect of control functions on managerial decision making.

\begin{tabular}{|l|c|c|c|}
\hline Statement & $\mathbf{N}$ & {$[\%]$} & \% Cumulative [\%] \\
\hline Does not affect & 16 & 4.1 & 4.1 \\
\hline Mildly affects & 116 & 29.6 & 33.7 \\
\hline Affects & 208 & 53.1 & 86.7 \\
\hline Significantly affects & 52 & 13.3 & 100.0 \\
\hline Total & 392 & 100.0 & $\mathrm{x}$ \\
\hline
\end{tabular}


PROBLEMS OF MANAGEMENT IN THE $21^{\text {st }}$ CENTURY Volume 3, 2012

Table 6. Positive and negative influence of the control system on managerial decision making

\begin{tabular}{|l|c|}
\hline Influence /from negative to positive/ & Answers [\%] \\
\hline - It complicates the right decision making. & 1.1 \\
\hline - It confuses me during decision making. & 1.1 \\
\hline - It slows down my decision making. & 4.3 \\
\hline + It speeds up my decision making. & 19.1 \\
\hline + It significantly simplifies my decision making. & 22.3 \\
\hline +It confirms and validates my assumptions to decision making. & 28.7 \\
\hline + It mildly helps me with decision making. & 29.8 \\
\hline + It enables correct decision making. & 39.4 \\
\hline + It alerts me to the need of decision making. & 40.4 \\
\hline
\end{tabular}

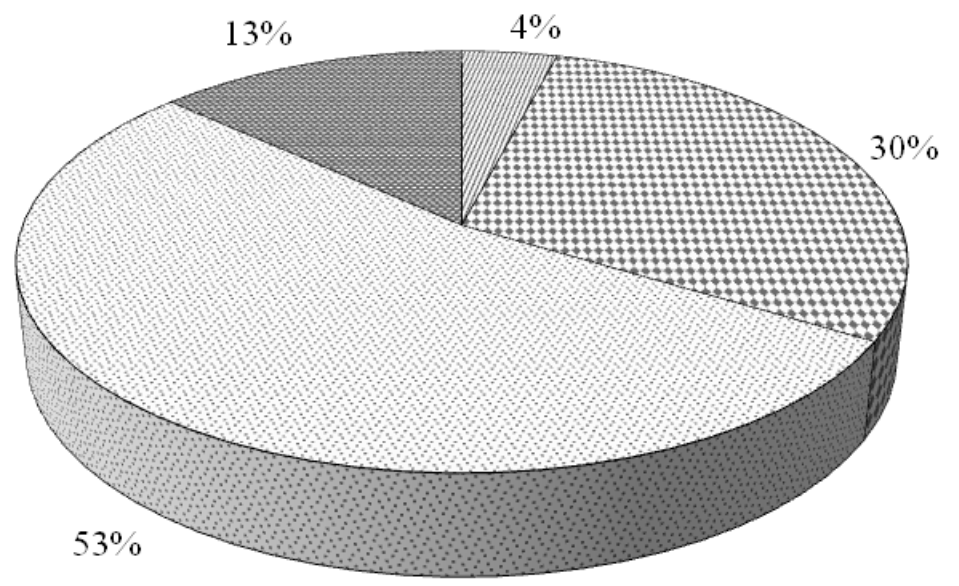

QDoes not affect

vMildly affects

田 Affects

圆 Significantly affects

\section{Figure 5: Opinions of the managers on the control system influence on their decision making.}

According to the obtained results we can state, that the control functions, control system and its outputs have a significant impact on managerial decision making (more than 51\% answers), resp. have a decisive effect on decision making (more than $13 \%$ ).

A negligible part of managers does not feel affected by the control activities, resp. control system (4\%) and a significant part (almost $30 \%$ ) is affected only a little.

Examination of the control system types of influences on managerial decision making

The types of negative and positive influences of control system on managerial decision making were determined according to the evaluation of the survey question: "How does the control or the control system influence your decision making?" 
A) Construction and the objective of the question

The question was made as semi-open. The managers could choose several given examples of influence but they could also write their own suggestions.

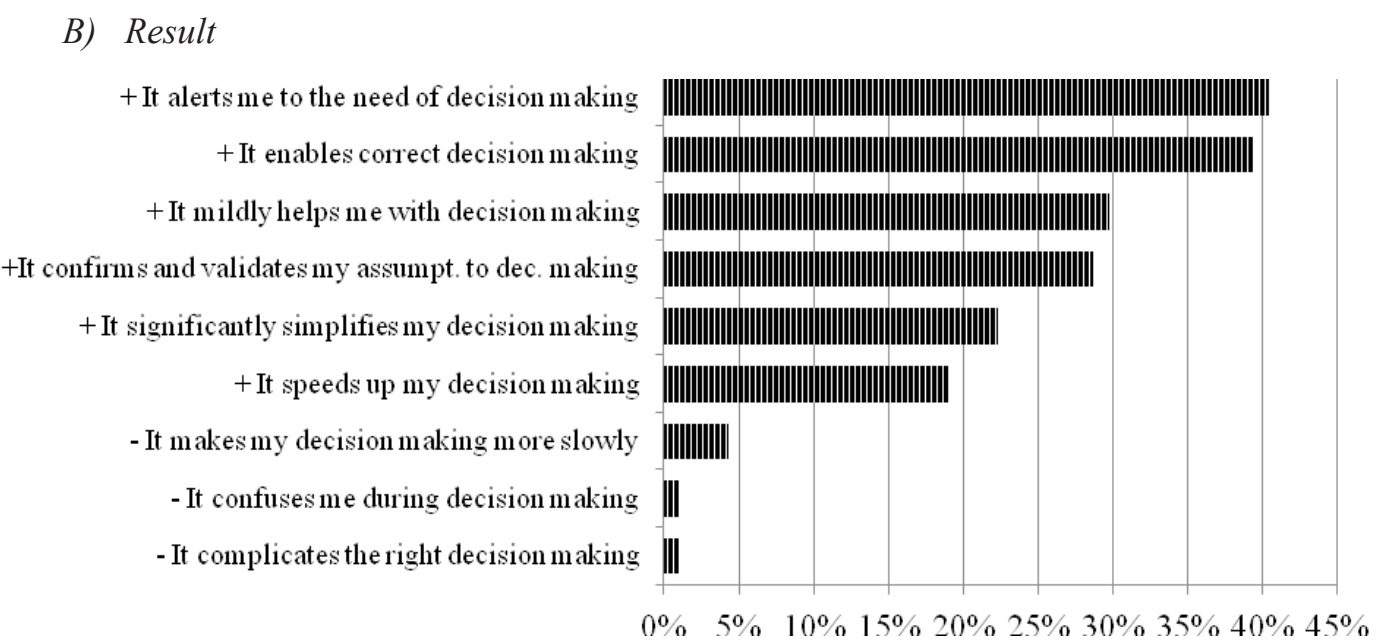

Figure 6: Perception of the control system by the managers.

The majority stated that the control system alerts them to the need of making a decision $(40 \%)$ and the second most frequent statement was that the control system enables correct decision making (more than 39\%). Many times they also stated that the control systems mildly help them with decision making (nearly 30\%), it confirms and validates their assumptions to decision making (approx. 29\%), it significantly simplifies their decision making (22\%) and it speeds up their decision making (19\%).

There were very few examples of negative influences of the control system. The options it slows down my decision making, it confuses me during decision making, and it complicates the right decision making appeared in a negligible number.

\section{Discussion}

Considering a standard 40-hour working time per week, managers use approximately 20 hours to deal with their control and decision making functions. According to the research, the control activities outputs have more positive than negative influence on the managerial decision making functions. However, these results come from a research based on subjective responses of managers. Further research should be carried out by a direct and independent measurement during the work of a particular manager.

Apart from the partial results, which are presented in this article, the research brought more data related to the company's control system. These data were obtained from processing the managers' opinions on the factors which influence the creation and further existence of the control system, what content, form and amount of information the control system provides them and if they are satisfied with the quality of these data and their application in the process of the decision making.

It is important to make all these data accessible to the scientific community, as we have not found similar information from such research in the available literature. 
PROBLEMS

OF MANAGEMENT

IN THE $21^{\text {st }}$ CENTURY

Volume 3, 2012

\section{Conclusion}

It is possible to draw certain conclusions from the above mentioned partial research results. The aim of the article was to identify the share of control and decision functions on the total managerial work. The evaluation clearly indicates that the share of the control functions is in average $21 \%$ of the managerial work and the share of decision making functions goes up to nearly $30 \%$.

These figures highlight the importance of these two managerial functions, because together they represent approximately half of the whole managerial work, which is a very high share. However, these findings do not have to reflect the reality completely, which was caused by the fact that the managers provided their answers based on their subjective estimate, not on real and independent measurement. This could be an objective of a next research.

A further partial conclusion is the fact that the majority of managers $(96 \%)$ admit a significant influence of control functions and control system on their decision making.

Finally we can declare that managers not only admit the influence of control function on their decision making, but they also appreciate its positive effects $(93.5 \%)$.

\section{Acknowledgements}

The authors would like to thank all colleagues and survey participants who contributed to this study.

\section{References}

Hunčík, B. (2006). Slovenský l'udský kapitál - jeho výkonnost' a „work-life balance“. PricewaterhouseCoopers. Retrieved 03/13/2012, from http://www.pwc.com/sk SK/sk/odborneclanky/assets/articleforhn29.pdf

Majtán, M. (2009). Manažment. Bratislava: Sprint dva.

Majtán, Š, (2009). Podnikové hospodárstvo. Bratislava: Sprint dva.

Porvazník, J. (2011). Celostný manažment. Bratislava: Sprint dva.

Synek, M. (2011). Manažerská ekonomika. Praha: Grada Publishing.

Szabo, L., \& Jankelová, N. (2010). Podnikatel’ské rozhodovanie. Bratislava: Ekonóm.

Veber, J. (2009). Management. Základy-moderní manažerské př́stupy-výkonnost a prosperita. Praha: Management Press.

Zuzák, R., \& Königová, M. (2009). Krizové ř́zení podniku. Praha: Grada Publishing.

Advised by Miroslav Majtan, University of Economics in Bratislava, Slovakia

Received: February 29, 2012

Accepted: April 06, 2012

\begin{tabular}{|ll} 
Jan Kráčmar & $\begin{array}{l}\text { Doc., Ing., CSc. Docent, University of Economics in Bratislava, Faculty of Man- } \\
\text { agement, Dolnozemska cesta 1, } 85235 \text { Bratislava, Slovakia. } \\
\text { E-mail: jan.kracmar@euba.sk }\end{array}$ \\
\hline Miroslav Uhliar & $\begin{array}{l}\text { Ing., PhD., Lecturer, University of Economics in Bratislava, Faculty of Manage- } \\
\text { ment, Dolnozemska cesta 1, 852 35 Bratislava, Slovakia. } \\
\text { E-mail: miro.uhliar@gmail.com }\end{array}$
\end{tabular}

